\title{
Koleksi bambu Taman Eden 100, Kabupaten Toba Samosir, Sumatera Utara dan perannya dalam taman
}

\author{
I Putu Gede P. Damayanto \\ Bidang Botani, Pusat Penelitian Biologi - Lembaga IImu Pengetahuan Indonesia (LIPI), \\ Jl. Jakarta-Bogor Km 46 Cibinong, Bogor, Jawa Barat, 16911, Indonesia \\ E-mail: parlida.damayanto.tab@gmail.com
}

\begin{abstract}
Bamboo Collections of Taman Eden 100, Toba Samosir Regency, North Sumatra and Its Role in the Garden. The aims of this study are to reveal and describe the collections of bamboo species and its role in Taman Eden 100 landscape. The study was conducted using the explore method, located in Taman Eden 100, Lumban Julu Sub-district, Toba Samosir Regency, North Sumatra. The bamboo herbarium specimens are made to determine the species of each collection of Bamboo of Taman Eden 100. The bamboo specimens are processed and then shipped to the Herbarium Bogoriense (BO) for further identification. The morphology characters also described and to be used in the analysis of the role of each bamboo within Taman Eden 100 landscape. The results showed that Taman Eden 100 has as many as four species of bamboo collections from 10 clumps, namely Bambusa multiplex (bambu cina), Bambusa vulgaris (bambu ampel), Dendrocalamus asper (bambu betung) and Schizostachyum silicatum (bambu suling). Each species of bamboo has different roles in different locations. Some properties of bamboo such as the presence or absence of hairs, culm diameter, culm length, ability in waterlogged or drought conditions and its benefits can be the consideration in choosing the bamboo species and location of planting in a garden.
\end{abstract}

Keywords: bamboo, Taman Eden 100, role in garden

\section{Pendahuluan}

Tanaman bambu sudah lama dikenal oleh masyarakat sebagai salah satu elemen lunak pada taman. Keberadaan bambu pada taman yang didominasi oleh pepohonan dapat membuat tampilan taman menjadi tidak terkesan monoton akibat perawakannya yang menarik dan berbeda dari pohon pada umumnya. Sesungguhnya, keberadaan bambu pada suatu taman memiliki peran secara ekologis dan sosial budaya. Secara ekologis, bambu dilaporkan berpotensi dijadikan sebagai tanaman konservasi lingkungan (MF, 2018). Berdasarkan penelitian Raka, dkk. (2011), menyatakan bahwa terjadi peningkatan debit air sebesar 10\% pada lahan marginal setelah ditanam bambu. Sistem perakaran tanaman bambu yang sangat rapat dan menyebar ke segala arah menjadi alasan bambu dapat menjadi tanaman konservasi air dan tanah (Sulistianto, 2017; MF, 2018). Akar-akar tersebut mampu menjaga ketersediaan air tanah dan sekaligus menjaga struktur tanah tetap stabil. Sementara itu, tanaman bambu mampu menyerap air hujan yang cukup besar, sehingga kemungkinan terjadinya aliran langsung dan erosi di atas permukaan tanah menjadi kecil (Sulistianto, 2017). Penggunaan bambu sebagai tanaman konservasi air dan tanah sudah dilakukan Cina dan India (MF, 2018). Di sisi lain, tanaman bambu juga dapat meningkatkan penyerapan karbon (Sulistianto, 2017) yang berfungsi mengurangi gas rumah kaca dari kendaraan bermotor di sekitar taman yang berbahaya bagi lingkungan.

Secara sosial budaya, bambu telah lama dikenal sebagai bagian dari kegiatan seni maupun adat masyarakat Indonesia (Sulistianto, 2017). Keberadaan bambu pada suatu taman atau kebun dianggap sakral dan tidak boleh dirusak seperti misalnya yang terjadi di kebun bambu Desa Penglipuran, Bangli, Bali. Secara konservasi, anggapan bahwa bambu itu sakral dapat menjadi keuntungan karena dapat menjaga kelestarian bambu itu sendiri pada suatu taman atau kebun. Selain itu, tanaman bambu juga memiliki sejarah tersendiri dalam perjuangan pada saat merebut kemerdekaan Indonesia tahun 1945. Bambu runcing digunakan sebagai senjata tradisional dalam berperang melawan penjajahan pada saat itu. Sehingga beberapa taman monumen perjuangan di Indonesia menggunakan bambu baik sebagai elemen lunak maupun keras taman tersebut. Sebagai contoh, elemen lunak berupa tanaman bambu kuning dijadikan simbol perjuangan dan ditanam pada Taman Monumen 45 Kota Pekalongan (Rochim \& Syahbana, 2013). Sementara itu, elemen keras berupa tugu bambu runcing digunakan sebagai focal point pada Taman Monumen Bambu Runcing di Kota Surabaya (Tauhid, 2018) dan pada Taman Digulis di Kota Pontianak (Liberani, 2017). Berdasarkan data tersebut, wajar jika bambu berperan atau dimanfaatkan sebagai salah satu elemen taman. 
Salah satu taman yang memanfaatkan bambu sebagai elemen di dalamnya adalah Taman Eden 100 yang berlokasi di Sumatera Utara. Selain memiliki koleksi bambu, Taman Eden 100 juga memiliki beberapa objek wisata lainnya seperti pembibitan tanaman, panggung pergelaran, area perkemahan, taman anggrek, kebun stroberi, kantin yang menyediakan minuman hasil kebun, air terjun di tiga lokasi berbeda, rumah tarzan (rumah pohon dengan tinggi $\pm 10 \mathrm{~m}$ ), lokasi pengamatan harimau, gua kelelawar, jalur pendakian, puncak Gunung Pangulubao dan puncak Bukit Manja (Marpaung, dkk., 2015). Bukit Manja di Taman Eden 100 adalah ekowisata dengan nilai kelayakan tertinggi untuk dikunjungi menurut Barus, dkk. (2016). Selain itu, taman ini juga membebaskan pengunjungnya menikmati buah-buahan yang ditanam (PKTS, 2014), namun tidak termasuk buah stroberi. Terdapat beberapa area hutan pinus yang cocok untuk melakukan swafoto selain juga hutan tropis alami yang cukup lebat. Setiap pengunjung bisa menanam pohon di taman ini dan pohon yang ditanam dinamai sesuai nama penanamnya, namun pengunjung harus mengeluarkan biaya perawatannya (Karmin, 2018).

Konsep pelestarian alam yang diusung Taman Eden 100 (Awi, 2012) diduga menjadi daya tarik tersendiri bagi pengunjung. Menurut pemilik taman ini, berwisata sambil belajar tentang alam dan pelestarian lingkungan menjadi pertimbangan bagi para pengunjung untuk datang ke Taman Eden 100 disamping harga tiket masuk yang tidak dipandang mahal. Selain itu, berwisata ke Taman Eden 100 cocok bagi seluruh anggota keluarga. Hadirnya berbagai pohon buah-buahan dan adanya taman anggrek di area Taman Eden 100 yang telah diberi label nama jenis tumbuhannya menjadikan taman ini layak dijadikan taman untuk rerekreasi sambil belajar. Sayangnya, tidak semua tumbuhan diberi label nama terutama rumpun bambu yang ditanam di taman ini. Padahal informasi ilmiah, misalnya nama jenis bambu tersebut, sangat layak ditampilkan di Taman Eden 100, mengingat kekayaan jenis tertinggi bambu di Indonesia dilaporkan ada di Sumatera (Widjaja, dkk., 2014; Damayanto \& Widjaja, 2017). Ironisnya, masyarakat setempat tidak menyadari kekayaan jenis bambu yang mereka miliki.

Perlu dilakukan penelitian terkait keragaman koleksi bambu di Taman Eden 100 sehingga diperoleh informasi tentang nama jenis dan deskripsi morfologi setiap bambu di taman tersebut. Sebagai tambahan, perlu juga dilakukan analisis terkait peran masing-masing jenis bambu tersebut terhadap lanskap Taman Eden 100 , mengingat tidak semua jenis bambu cocok ditanam pada lanskap sebuah taman. Bambu terkadang membuat pengunjung tidak nyaman karena dapat menyebabkan gatal dan dapat menggangu keberlangsungan hidup tumbuhan lain disekitarnya seperti terjadinya persaingan memperoleh cahaya. Selain itu, adanya zat alelopati pada seresah daun bambu yang menyebabkan tanah yang tertimbun seresah tidak akan ditumbuhi tumbuhan lain (Damayanto \& Muhaimin, 2017). Hasil penelitian ini dapat dijadikan acuan untuk pengelolaan Taman Eden 100 di masa depan.

\section{Metode}

Penelitian dilakukan pada bulan Maret 2018 dengan menggunakan metode Jelajah dari Rugayah, dkk. (2004). Penelitian berlokasi di Taman Eden 100 (Gambar 1) yang secara administrasi termasuk ke dalam Kecamatan Lumban Julu, Kabupaten Toba Samosir, Sumatera Utara. Secara geografis, lokasi penelitian terletak pada koordinat N 02³5'32,8" E 09902'21,7" dengan ketinggian 1.100 - 1.272 m dpl.

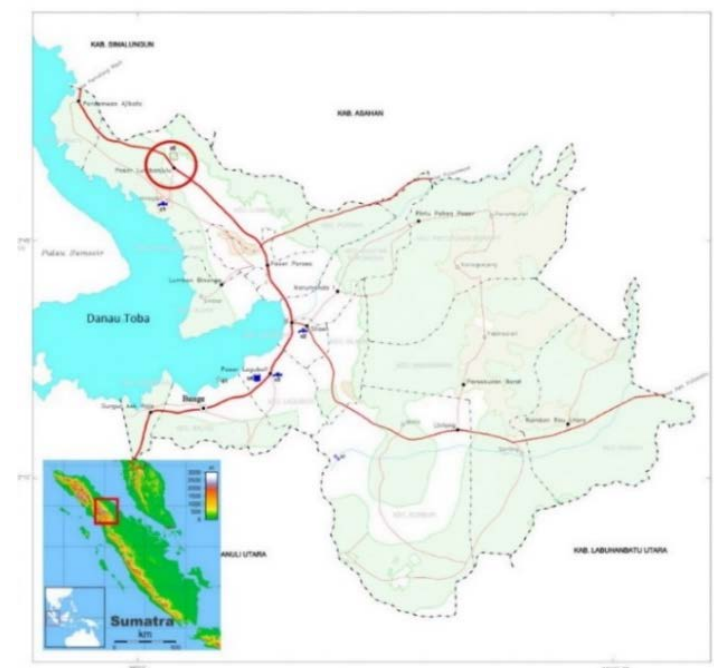

Gambar 1. Lokasi Penelitian (Lingkaran Merah) di Taman Eden 100, Kec. Lumban Julu, Kab. Toba Samosir, Sumatera Utara (Modifikasi Peta KPU, 2012) 
Untuk mengetahui jenis-jenis bambu yang ditanam di Taman Eden 100 maka dilakukan pembuatan spesimen herbarium bambu. Material bambu yang fertil (dengan bunga dan atau buah) maupun steril (tanpa bunga dan buah) dikoleksi mengikuti metode McClure (1945). Bambu steril tetap dikoleksi karena bambu jarang berbunga. Proses identifikasi hingga tingkat jenis pada bambu steril masih bisa dilakukan asalkan paling tidak tersedia spesimen rebung, pelepah buluh dan percabangan daun. Material bambu yang dikoleksi diberi kode nama pengoleksi dan nomor koleksi. Informasi penunjang lainnya dicatat seperti lokasi dan koordinat GPS, ketinggian tempat, tanggal koleksi, nama daerah (jika ada), manfaat (jika ada), karakter morfologi yang akan hilang saat dikeringkan, serta habitat. Spesimen diselipkan dalam koran dan disiram dengan alkohol 70\% atau spritus lalu dikemas dan dikirim ke Herbarium Bogoriense (BO) untuk proses pengeringan, identifikasi dan pengeplakan pada kertas yang mengikuti metode Djarwaningsih, dkk. (2002). Spesimen diidentifikasi menggunakan spesimen acuan dari BO dan pustaka seperti Dransfield (1980), Widjaja (1987), Dransfield \& Widjaja (1995), Widjaja (1997; 2001a; 2001b), Widjaja \& Karsono (2005), Widjaja, dkk. (2005) dan Damayanto \& Widjaja (2016; 2017). Bambu yang telah diidentifikasi kemudian dideskripsikan karakteristik morfologinya untuk digunakan dalam analisis peran masing-masing jenis bambu tersebut terhadap lanskap Taman Eden 100.

\section{Hasil dan Pembahasan}

3.1. Hasil Penelitian

Hasil eksplorasi diperoleh sebanyak empat jenis dari 10 rumpun bambu yang ditanam di Taman Eden 100 seperti terlihat pada Tabel 1.

Tabel 1. Koleksi Bambu Taman Eden 100

\begin{tabular}{cllcl}
\hline No. & Nama Latin & Nama Indonesia & $\begin{array}{c}\text { Jumlah } \\
\text { Rumpun }\end{array}$ & Kondisi \\
\hline 1. & $\begin{array}{l}\text { Bambusa multiplex (Lour.) Raeusch. } \\
\text { ex. J.A. \& J.H. Schult. }\end{array}$ & Bambu cina & 2 & Dewasa, fertil \\
2. & Bambusa vulgaris Schrad. ex. Wendl. & Bambu ampel & 1 & Anakan, steril \\
3. & $\begin{array}{l}\text { Dendrocalamus asper (Schult.) } \\
\text { Backer ex. Heyne }\end{array}$ & Bambu betung & 3 & Dewasa, steril \\
4. & Schizostachyum silicatum Widjaja & Bambu suling & 4 & Dewasa, steril \\
\hline
\end{tabular}

\subsection{Pembahasan}

\subsubsection{Gambaran Umum Taman Eden 100}

Taman Eden 100, secara administrasi berada di Desa Sionggang Utara, Kecamatan Lumban Julu, Kabupaten Toba Samosir, Sumatera Utara (Telaumbanua, 2011; Awi, 2012; Karmin, 2018), tepatnya di Jalan Parapat-Porsea kilometer 16 (Awi, 2012). Secara geografis, Taman Eden 100 terletak diantara 20³9' LU sampai $20^{\circ} 42^{\prime}$ LU dan 9862' BT sampai 9864' BT (Telaumbanua, 2011) pada ketinggian 1.100-1.750 m dpl (PKTS, 2014; Sinaga, dkk., 2016). Secara keseluruhan, Taman Eden 100 memiliki luas sekitar 1.980 ha (Sinaga, dkk. 2016) dan sekitar 40 ha area tersebut dikelola oleh Yayasan Elsaddai (Telaumbanua, 2011) dengan ketua saat ini adalah Marandus Sirait. Dari \pm 1.980 ha tersebut, lebih dari 1.800 ha merupakan hutan alami (Lubis, 2009; Sinaga, dkk., 2016) dan lebih dari 900 ha merupakan tebing tinggi dan jurang terjal (Telaumbanua, 2011). Untuk menuju ke Taman Eden 100, perlu waktu 3-4 jam dari Medan atau sekitar 190 km (Karmin, 2018). Sementara dari kota terdekat, Kota Parapat, Taman Eden 100 berjarak sekitar $16 \mathrm{~km}$ atau sekitar 55 km dari Kota Balige (Lubis, 2009).

Taman Eden 100 merupakan kawasan tanah adat yang diwariskan dari keluarga Leas Sirait yang selanjutnya diteruskan keturunannya, Marandus Sirait (Sinaga, dkk., 2016). Awalnya taman ini difungsikan sebagai kawasan wisata rohani umat Nasrani oleh keluarga Sirait, hingga tahun 2000 diresmikan menjadi daerah konservasi oleh Pemerintah Kabupaten Toba Samosir (Telaumbanua, 2011) dan hingga kini dibuka untuk umum. Nama "Eden" diberikan berdasarkan pada keyakinan bahwa taman tersebut diharapkan menjadi semacam surga bagi manusia (Faiq, 2012) dan nama "100" didasari dari pembukaan awal taman tersebut degan menanam 100 jenis pohon yang buahnya dapat dimakan (Telaumbanua, 2011; PKTS, 2014).

Salah satu faktor pendukung pengembangan objek wisata Taman Eden 100 ini menurut Sitorus (2016) adalah tersedianya fasilitas umum seperti tanda petunjuk arah yang jelas dan waktu yang tidak terlalu lama 
menuju taman ini serta biaya yang dikeluarkan untuk menikmati taman ini tidak terlalu mahal. Dengan tiket masuk Rp.10.000 per orang (Karmin, 2018) dirasa tidak memberatkan bagi pengunjung Taman Eden 100. Selain itu, faktor ekologi seperti suhu lingkungan yang tergolong sejuk, $20^{\circ} \mathrm{C}$, di siang hari (PKTS, 2014), kelembaban udara yang relatif tinggi, 70-93\% (Telaumbanua, 2011) dan intensitas cahaya 180-600 Lux (Lubis, 2009) menambah kenyamanan pengunjung untuk berwisata di Taman Eden 100. Terbukti dalam sebulan, rata-rata pengunjung mencapai 1.200 orang bahkan hingga 100 orang per hari pada Juni-Juli, saat liburan sekolah (Faiq, 2012). Sementara data tahun 2013, terdapat 16.481 pengunjung dan tahun 2014 sebanyak 12.356 pengunjung di Taman Eden 100 (Sitorus, 2016).

\subsubsection{Deskripsi Koleksi Bambu Taman Eden 100}

Untuk menentukan kesesuaian setiap jenis bambu yang ditanam di Taman Eden 100, maka perlu dilakukan pertelaan (pendeskripsian) morfologi masing-masing jenis bambu tersebut. Hasil pertelaan tersebut digunakan untuk menjabarkan peran setiap bambu terhadap lanskap Taman Eden 100. Berikut disajikan deskripsi setiap jenis bambu yang ditanam di Taman Eden 100 beserta dengan foto setiap jenisnya.

1. Bambusa multiplex (Gambar 2.A.)

Rumpun padat, rebung hijau dan gundul. Buluh tingginya 3-4 m, tumbuh tegak dengan ujung melengkung. Widjaja (2001b) melaporkan bambu ini dapat tumbuh hingga mencapai $8 \mathrm{~m}$. Percabangan muncul dekat permukaan tanah dengan lebih dari 7 cabang yang hampir sama besarnya. Ruas pada buluh panjangnya lebih dari $20 \mathrm{~cm}$ dengan diameter hingga $2 \mathrm{~cm}$. Pelepah buluh gundul dan mudah luruh. Kuping pada pelepah buluh berbentuk bingkai dan memiliki bulu kejur yang pendek. Ligula pada pelepah buluh menggerigi tidak teratur dan gundul. Daun pelepah buluh tegak dan berbentuk segitiga dengan pangkal melebar. Daun berbentuk pita dengan ukuran 6-11 × 0.5-1 cm. Kuping pada pelepah daun kecil dengan bulu kejur yang pendek. Ligula pada pelepah daun menggerigi.

2. Bambusa vulgaris (Gambar 2.B.)

Rumpun agak renggang, rebung kuning tertutup miang coklat hingga hitam. Buluh tegak, tinggi mencapai $20 \mathrm{~m}$ (Widjaja, 2001a). Percabangan muncul $1.5 \mathrm{~m}$ dari permukaan tanah dengan cabang berjumlah hingga 5 buah yang salah satu cabangnya lebih besar dari yang lain. Ruas pada buluh panjangnya $20-45 \mathrm{~cm}$ dengan diameter 5-10 cm (Widjaja, 2001b). Pelepah buluh mudah luruh dan tertutup miang coklat tua hingga hitam. Kuping pada pelepah buluh membundar dengan ujung melengkung ke luar dan memiliki bulu kejur. Ligula pada pelepah buluh menggerigi dengan bulu kejur pendek. Daun pelepah buluh tegak dan berbentuk segitiga dengan pangkal melebar. Daun berbentuk pita dengan ukuran 10-17 × 1-3 cm. Kuping pada pelepah daun kecil dengan bulu kejur yang pendek. Ligula pada pelepah daun rata.

3. Dendrocalamus asper (Gambar 2.C.)

Rumpun agak padat, rebung hitam keunguan tertutup miang coklat hingga hitam yang sangat tebal. Buluh tegak dengan ujung melengkung dan tinggi lebih dari $20 \mathrm{~m}$. Percabangan muncul dari pertengahan buluh dengan cabang berjumlah hingga 10 buah yang salah satu cabangnya lebih besar dari yang lain. Ruas pada buluh panjangnya mencapai $40 \mathrm{~cm}$ dengan diameter $15-20 \mathrm{~cm}$. Pelepah buluh mudah luruh dan tertutup miang coklat tua hingga hitam yang sangat tebal. Kuping pada pelepah buluh mengeriting dan memiliki bulu kejur. Ligula pada pelepah buluh menggerigi tidak beraturan dengan bulu kejur yang pendek. Daun pelepah buluh terkeluk balik dan berbentuk segitiga dengan pangkal agak melebar. Daun berbentuk pita dengan ukuran $20-33 \times 3-4.5 \mathrm{~cm}$. Kuping pada pelepah daun kecil dan gundul. Ligula pada pelepah daun rata dengan bulu kejur yang pendek.

\section{Schizostachyum silicatum (Gambar 2.D.)}

Rumpun sangat padat, rebung hijau tertutup miang putih hingga cokelat. Buluh tegak dan tingginya mencapai lebih dari $6 \mathrm{~m}$. Percabangan muncul $1.5 \mathrm{~m}$ dari permukaan tanah dengan cabang hingga lebih dari 7 buah yang hampir sama besarnya. Ruas pada buluh panjangnya $50-60 \mathrm{~cm}$ dengan diameter $2-3 \mathrm{~cm}$. Pelepah buluh tidak mudah luruh, tertutup miang putih hingga cokelat muda. Kuping pada pelepah buluh tidak tampak dengan bulu kejur yang mudah patah. Ligula pada pelepah buluh menggerigi dengan bulu kejur yang tipis. Daun pelepah buluh terkeluk balik dan berbentuk pita atau melanset. Daun berbentuk pita dengan ukuran $19-28 \times 3-4 \mathrm{~cm}$. Kuping pada pelepah daun kecil dengan bulu kejur panjang. Ligula pada pelepah daun rata dan gundul. 

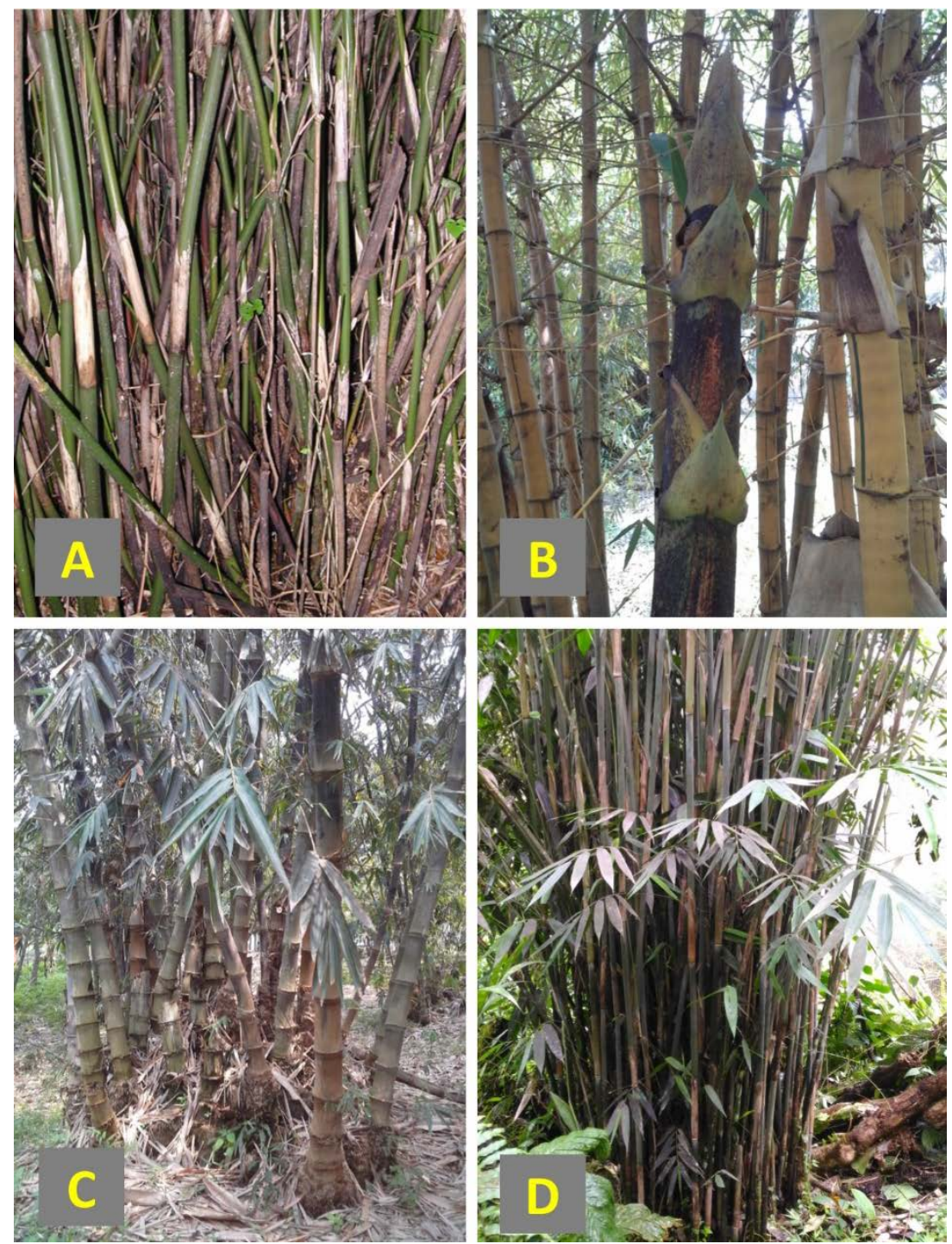

Gambar 2. Bambusa multiplex (A). Bambusa vulgaris (B). Dendrocalamus asper (C). Schizostachyum silicatum (D). (Foto: I Putu Gede P. Damayanto)

\subsubsection{Peran Bambu dalam Lanskap Taman Eden 100}

Berdasakan hasil identifikasi jenis dan deskripsi morfologi setiap jenis bambu koleksi Taman Eden 100 maka dapat dijabarkan peran masing-masing jenisnya terhadap lanskap taman. Peran yang dimaksud bisa jadi peran positif yang mendukung secara umum lanskap taman dan atau bisa juga berperan negatif seperti menjadi sumber kerusakan dan ketidaknyamanan pada taman. Setiap jenis bambu memiliki peran yang berbeda pada lokasi yang berbeda. Dengan kata lain, jenis bambu yang sesuai ditanam di suatu lokasi belum tentu sesuai jika ditanam di lokasi yang lain. Beberapa sifat bambu seperti ada tidaknya miang, diameter buluh, tinggi buluh, kemampuan beradaptasi dalam kondisi tergenang air atau kekeringan dan kegunaannya dapat menjadi pertimbangan dalam memilih jenis bambu dan lokasi tanamnya dalam sebuah taman.

Rumpun dari jenis Bambusa multiplex (bambu cina) dijadikan tanaman pagar dan pergola pada gerbang kebun stroberi di Taman Eden 100. Jenis bambu ini sudah lama dikenal sebagai tanaman pagar (Widjaja, 2001b) bahkan dapat ditanam dalam pot sebagai tanaman hias (Widjaja, dkk., 2005). Kelebihan bambu ini sebagai tanaman pagar adalah tahan dipangkas (Arinasa \& Peneng, 2013), mudah dibentuk karena rumpunnya yang rapat dengan diameter buluh yang kecil, selain juga rebung dan pelepah buluhnya yang gundul (tidak ada miang) sehingga tidak akan membuat gatal. Sayangnya, bambu ini bukanlah jenis asli Indonesia melainkan jenis introduksi (Widjaja, 2001a) dari Cina (Arinasa \& Peneng, 2013). Bambu ini sangat sesuai menjadi pagar dan pergola gerbang kebun stroberi di Taman Eden 100 karena sudah sesuai dengan konsep taman yang meminimalisasi penggunaan elemen keras seperti tembok semen atau besi. 
Bambu jenis Bambusa vulgaris (bambu ampel) yang dijumpai di Taman Eden 100 masih dalam kondisi anakan dan ditanam dalam pot. Jenis ini tampaknya merupakan varietas $B$. vulgaris var. striata dengan buluh yang berwarna kuning bergaris hijau. Dransfield \& Widjaja (1995) menyatakan bahwa $B$. vulgaris memiliki tiga varietas yaitu $B$. vulgaris var. vulgaris (buluh hijau), $B$. vulgaris var. striata (buluh kuning bergaris hijau) dan $B$. vulgaris var. wamin (buluh hijau menggembung). Bambu B. vulgaris var. striata yang ada di Taman Eden 100 perlu dipindahkan dari pot dan ditanam pada lokasi yang cukup luas dan terbuka karena jenis ini memiliki rumpun yang agak renggang, rimbun, dan percabangan dekat dengan tanah serta dapat mencapai tinggi 20 $\mathrm{m}$ setelah dewasa. Lokasi tanam dapat berupa area yang sering tergenang air atau bahkan kering sekalipun karena jenis bambu ini tahan genangan (2-3 bulan) dan kekeringan (Widjaja, 2001b). Bambu ini dapat meningkatkan tampilan lanskap taman karena memiliki warna buluh kuning bergaris hijau yang indah. Bambu ini juga dapat digunakan sebagai point of view pada taman yang didominasi warna hijau dedaunan.

Terdapat satu rumpun dari jenis Dendrocalamus asper (bambu betung) yang lokasi tanamnya kurang tepat karena ditanam tepat pada lereng yang terjal. Seperti diketahui, Taman Eden 100 memiliki kontur lanskap berbukit-bukit dengan lereng terjal (Telaumbanua, 2011), sehingga jenis $D$. asper yang memiliki diameter buluh besar dan tinggi buluhnya mencapai lebih dari $20 \mathrm{~m}$ akan berpotensi roboh karena buluhnya yang berat dan tinggi ditambah lagi dengan lokasi tumbuh berupa lereng terjal. Jika bambu tersebut roboh maka akan ikut mengangkat tanah di sekitarnya dan berpotensi menimbulkan longsor. Terbukti terdapat beberapa titik longsor sekitar tumbuhnya rumpun bambu di Taman Eden 100. Bambu tersebut perlu direlokasi oleh pengelola Taman Eden 100. Di sisi lain, terdapat rumpun D. asper yang ditanam di tepi sungai besar dan dekat area perkemahan. Bambu D. asper sangat baik tumbuh pada tempat lembab (Widjaja, 2001b) seperti sekitar sungai, sehingga akan rajin menghasilkan rebung yang dapat dijadikan bahan makanan oleh pengunjung yang berkemah di Taman Eden 100. Arinasa \& Peneng (2013) menyatakan bahwa sayur dari rebung bambu D. asper banyak disukai karena memiliki rasa yang enak, tidak terlalu pahit dan keras serta ukurannya besar. Sayangnya, miang pada rebung bambu ini cukup banyak dan dapat membuat gatal. Di sisi lain, buluh bambu ini banyak digunakan dalam kontruksi bangunan (Widjaja, 2001b) sehingga dapat digunakan sebagai pilihan elemen keras yang masih alamai di Taman Eden 100 seperti dalam pembuatan jembatan dan pondok peristirahatan. Dengan demikian, kesan alami suatu elemen keras taman masih diperoleh selain juga dapat menekan pengeluaran dalam pengembangan dan pengelolaan taman.

Bambu Schizostachyum silicatum (bambu suling) ditaman di sekitar area kebun anggrek di Taman Eden 100 dan satu rumpun lainnya di dekat kantin. Jenis ini sepertinya tidak masalah jika ditempatkan di taman anggrek atau lokasi lainnya karena perawakannya yang hanya memiliki tinggi tidak lebih dari $12 \mathrm{~m}$ (Widjaja, 2001b) dan diameter buluh relatif kecil sekitar 2-3 cm. Bambu S. silicatum ini dapat mejadi naungan bagi anggrek di sekitarnya yang tidak bisa terkena cahaya matahari langsung. Selain itu, bambu $S$. silicatum juga dapat membantu menjaga kelembaban area taman seperti yang selalu dibutuhkan tanaman anggrek. Bambu S. silicatum dapat tumbuh di daerah bebatuan dan tanah marginal karena tampaknya bambu ini memiliki kemampuan adaptasi yang tinggi (Arinasa \& Peneng, 2013). Dengan demikian, dapat menekan pengeluaran biaya dalam perawatan bambu ini. Selain itu, bambu ini juga dapat dijadikan material elemen keras taman melengkapi jenis $D$. asper. Sifat buluh $S$. silicatum yang lebih tipis dapat dimanfaatkan sebagai anyaman untuk membuat pagar taman sehingga mengurangi biaya pembuatan elemen keras taman. Sayangnya, bambu $S$. silicatum memiliki miang yang cukup banyak dan terasa lebih gatal jika dibandingkan dengan jenis lainnya.

Agar keberadaan bambu di Taman Eden 100 berperan optimal mendukung konsep taman maka berikut disajikan ringkasan rekomendasi optimalisasi penggunaan empat jenis bambu tersebut disertai dengan ilustrasinya (Tabel 2).

Tabel 2. Rekomendasi Optimalisasi Pemanfaatan Empat Jenis Bambu di Taman Eden 100

\begin{tabular}{clll}
\hline No. & Jenis & Rekomendasi & \multicolumn{1}{c|}{ llustrasi* } \\
\hline 1. & Bambusa & Sebagai pagar hidup dan pergola \\
& multiplex & pada lahan kebun stroberi. \\
& (bambu cina) & Pengunaan pagar dari bambu akan \\
& mengurangi biaya pembangunan & \\
& tembok pembatas. Bambu ini tahan & \\
& dipangkas dan mudah dibentuk \\
& karena diameter buluh yang kecil \\
& sehingga cocok untuk dijadikan pagar \\
& hidup.
\end{tabular}




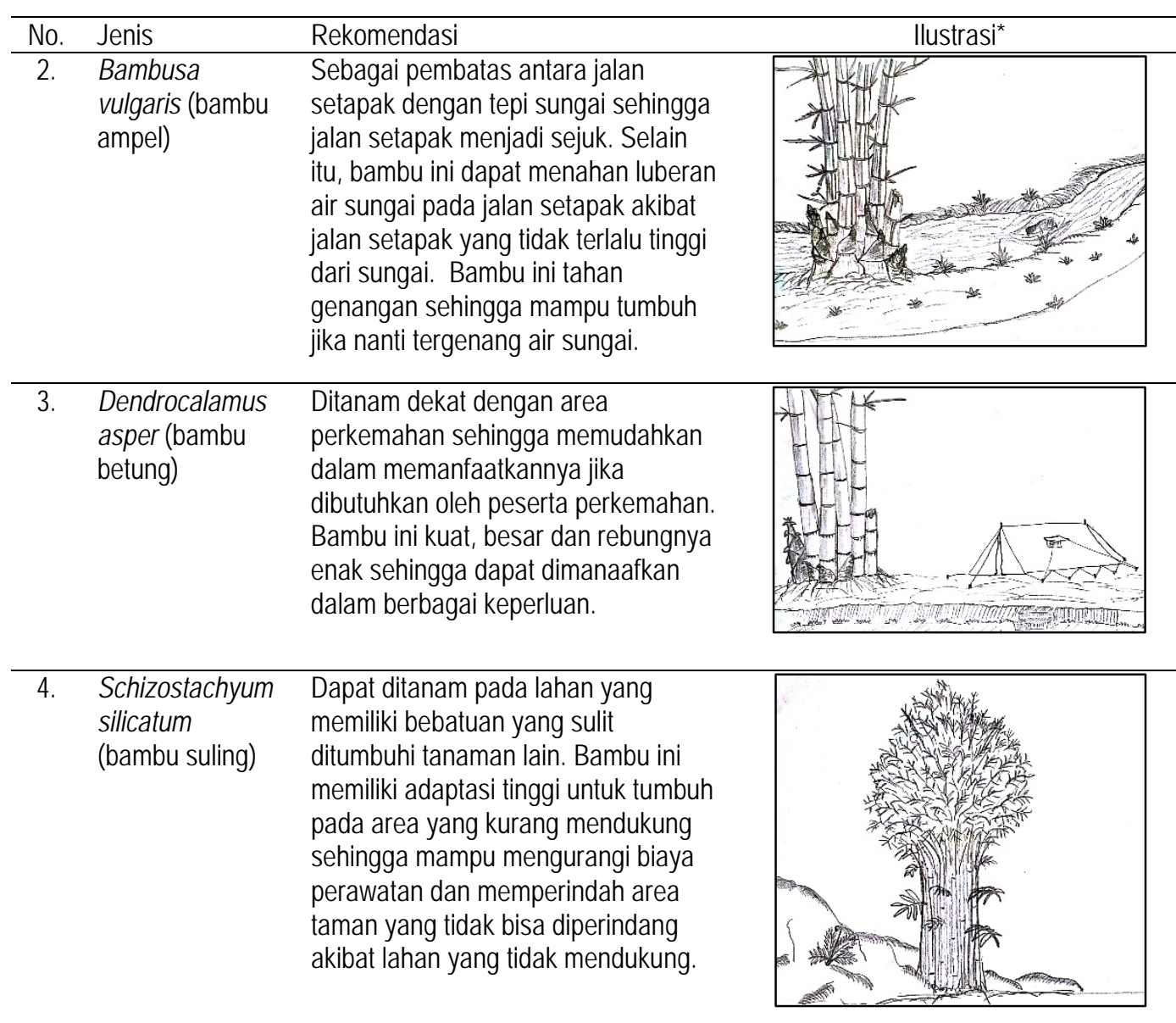

*llustrasi: I Putu Gede. P. Damayanto

\section{Simpulan}

Taman Eden 100 memiliki sebanyak empat jenis koleksi bambu dari 10 rumpun yang ditanam yaitu Bambusa multiplex (bambu cina), Bambusa vulgaris (bambu ampel), Dendrocalamus asper (bambu betung) dan Schizostachyum silicatum (bambu suling). Setiap jenis bambu memiliki peran yang berbeda pada lokasi yang berbeda. Beberapa sifat bambu seperti ada tidaknya miang, diameter buluh, tinggi buluh, kemampuan beradaptasi dalam kondisi tergenang air atau kekeringan dan kegunaannya dapat menjadi pertimbangan dalam memilih jenis bambu dan lokasi tanamnya dalam sebuah taman. Jenis B. multiplex dapat dijadikan tanaman pagar dan pergola. Jenis $B$. vulgaris dapat ditanam pada area tergenang air atau kering. Jenis $D$. asper dan S. silicatum dapat dimanfaatkan sebagai material elemen keras taman.

\section{Ucapan Terima Kasih}

Penulis mengucapkan terima kasih kepada Pusat Penelitian Biologi - LIPI yang telah mendanai dan memberikan kesempatan bagi penulis untuk melakukan ekspedisi ke Sekitar Danau Toba, Sumatera Utara. Terima kasih juga disampaikan kepada Kurator Herbarium Bogoriense (BO) atas ijin yang diberikan dalam pengamatan spesimen bambu. Terima kasih kepada para Pengelola Taman Eden 100 atas bantuan selama melakukan penelitian. Terima kasih kepada Kusuma Rahmawati, Kang Sarifudin dan Kang Agus Haryadi atas bantuan mereka selama mengoleksi spesimen bambu di Taman Eden 100.

\section{Daftar Pustaka}

Arinasa, I. B. K. \& I N. Peneng. 2013. Jenis-jenis bambu di Bali dan Potensinya. LIPI Press, Jakarta.

Awi. 2012. Satwa langka masih berkeliaran di "Taman Eden". Available online at: https://bengkulu.antaranews.com/berita/812/satwa-langka-masih-berkeliaran-di-taman-eden (diakses pada 2 Mei 2018). 
Barus, E. Rahmawaty \& P. Patana. 2016. Potensi wisata alam di Kesatuan Pengelolaan Hutan Lindung Model Unit XIV Toba Samosir (Potential of ecotourism at Unit XIV Toba Samosir Forest Management Unit). Peronema Forestry Science Journal 5(3): 162-167.

Damayanto, I P. G. P. \& E. A. Widjaja. 2016. A new species of Schizostachyum (Poaceae: Bambusoideae) from Sumba Island, Indonesia. Reinwardtia 15(2): 119-122.

Damayanto, I P. G. P. \& E. A. Widjaja. 2017. A noteworthy Dendrocalamus (Poaceae: Bambusoideae) from Sumatra, Indonesia. Gardens' Bulletin Singapore 69(1): 75-80.

Damayanto, I P. G. P. \& M. Muhaimin. 2017. Notes on Chimonobambusa quadrangularis (Franceschi) Makino (Poaceae: Bambusoideae) as an Invasive Alien Plant Species in Indonesia. Floribunda 5(7): 253-257.

Djarwaningsih, T., S. Sunarti \& K. Kramadibrata. 2002. Panduan pengolahan dan pengelolaan material herbarium serta pegendalian hama terpadu di Herbarium Bogoriense. Herbarium Bogoriense, Bidang Botani, Pusat Penelitian Biologi - LIPI, Bogor.

Dransfield, S. \& E. A. Widjaja (editor). 1995. Plant resousces of South-East Asia, no 7. bamboos. Backhuys Publishers, Leiden.

Dransfield, S. 1980. Three new Malesian species of Gramineae. Reinwardtia 9(4): 385-392.

Faiq, M. H. 2012. Merengkuh "surga" di Taman Eden 100. Editor: I Made Asdhiana. Available online at: https://travel.kompas.com/read/2012/01/12/06071268/merengkuh.quotsurgaquot.di.taman.eden.100 (diakses pada 2 Mei 2018).

Karmin. 2018. Taman Eden 100, eoknya wisata alam di Tepi Danau Toba. Available online at: https://travel.trubus.id/post/taman-eden-100-eoknya-wisata-alam-di-tepi-danau-toba-10149 (diakses pada 2 Mei 2018).

KPU (Kementrian Pekerjaan Umum). 2012. Peta infrastruktur Indonesia 2011 Kabupaten Toba Samosir. Available online at: http://loketpeta.pu.go.id/peta-infrastruktur-kabupaten-toba-samosir-2011\#panelinfo (diakses pada 1 Mei 2018).

Liberani, C. 2017. Banyak belum tahu, ini sejarah berdirinya Tugu Digulis, ceritanya bikin haru. Available online at: http://pontianak.tribunnews.com/2017/10/24/banyak-belum-tahu-ini-sejarah-berdirinya-tugudigulis-ceritanya-bikin-haru (diakses pada 8 Oktober 2018).

Lubis, S. R. 2009. Keanekaragaman dan pola distribusi tumbuhan paku di Hutan Wisata Alam Taman Eden Kabupaten Toba Samosir Provinsi Sumatera Utara. M.Si. Tesis (Unpublished) Sekolah Pascasarjana, Universitas Sumatera Utara.

Marpaung, R. A. Purwoko \& K. S. Hartini. 2015. Analisis potensi dan pengembangan kawasan wisata Taman Eden 100 Kecamatan Lumban Julu, Kabupaten Toba Samosir, Sumatera Utara (The analisys of potential and development of Taman Eden 100 tourism area, Subdistrict Lumban Julu, District Toba Samosir, North Sumatera). Peronema Forestry Science Journal 4(4): 1-15.

MF (Medco Foundation). 2018. Bambu sebagai tanaman konservasi. Available online at: http://www.medcofoundation.org/bambu-sebagai-tanaman-konservasi/ (diakses pada 8 Oktober 2018).

McClure, F. A. 1945. Suggestions on how to collect bamboos. Division of Latin American Agriculture, Office of Foreign Agricultural Relations, Washington DC.

PKTS (Pemerintah Kabupaten Toba Samosir). 2014. Pesona alam Taman Eden 100 Kabupaten Toba Samosir. Available online at: http://www.tobasamosirkab.go.id/pesona-alam-taman-eden-100kabupaten-toba-samosir/ (diakses pada 2 Mei 2018)

Raka, I. D. N., I. G. N. A. Wiswasta \& I. M. Budiasa. 2011. Pelestarian tanaman bambu sebagai upaya rehabilitasi lahan dan konservasi tanah di daerah sekitar mata air pada lahan marginal di Bali Timur. Agrimeta 1(1): 1-11.

Rochim, F. N. \& J. A. Syahbana. 2013. Penetapan fungsi dan kesesuaian vegetasi pada taman publik sebagai ruang terbuka hijau (RTH) di Kota Pekalongan (studi kasus: Taman Monumen 45 Kota Pekalongan). Jurnal Teknik PWK 2(3): 314-327.

Rugayah, E. A. Widjaja \& Praptiwi (editor). 2004. Pedoman pengumpulan data keanekaragaman flora. Pusat Penelitian Biologi-LIPI, Bogor.

Sinaga, V. A., D. Yoza \& T. Arlita. 2016. Analisis biaya dan manfaat ekowisata Taman Eden 100 Kecamatan Lumban Julu Kabupaten Toba Samosir Provinsi Sumatera Utara. Jom Faperta 3(2): 1-12.

Sitorus, L. S. 2016. Strategi pengembangan objek wisata Taman Eden 100 menjadi kawasan wisata di Desa Sionggang Utara Kecamatan Lumban Julu Kabupaten Toba Samosir. S.Sos. Skripsi (Unpublished) Jurusan Pendidikan Geografi, Fakultas IImu Sosial, Universitas Negeri Medan.

Sulistianto, I. 2017. Hutan bambu sebagai alternatif konservasi DAS. Available online at: http://konservasidas.fkt.ugm.ac.id/2017/06/21/hutan-bambu-sebagai-alternatif-konservasi-das/ (diakses pada 8 Oktober 2018). 
Tauhid. 2018. Senjata tradisional simbol perjuangan di Monumen Bambu Runcing. Available online at: https://www.indonesiakaya.com/jelajah-indonesia/detail/senjata-tradisional-simbol-perjuangan-dimonumen-bambu-runcing (diakses pada 8 Oktober 2018).

Telaumbanua, R. N. 2011. Wild orchids in Toba, pesona 100 anggrek hutan di Toba Samosir. CV. Solagratio Medan, Medan.

Widjaja, E. A. 1987. A Revision of Malesian Gigantochloa (Poaceae - Bambusoideae). Reinwardtia 10(3): 291-380.

Widjaja, E. A. 1997. New taxa in Indonesian bamboos. Reinwardtia 11(2): 57-152.

Widjaja, E. A. 2001a. Identikit jenis-jenis bambu di Kepulauan Sunda Kecil. Pusat Penelitian dan Pengembangan Biologi-LIPI, Bogor.

Widjaja, E. A. 2001b. Identikit jenis-jenis bambu di Jawa. Pusat Penelitian dan Pengembangan Biologi-LIPI, Bogor.

Widjaja, E. A. \& Karsono. 2005. Keanekaragaman bambu di Pulau Sumba. Biodiversitas 6(2): 95-99.

Widjaja, E. A., I. P. Astuti, I. B. K. Arinasa, I W. Sumantera. 2005. Identikit bambu di Bali. Bidang Botani, Pusat Penelitian Biologi - LIPI, Bogor.

Widjaja E. A., Y. Rahayuningsih, J. S. Rahajoe, R. Ubaidillah, I. Maryanto, E. B. Walujo \& G. Semiadi (editor). 2014. Kekinian keanekaragaman hayati Indonesia 2014. LIPI Press, Jakarta. 